\title{
$\checkmark$ Health professionals and human rights campaigners: different cultures, shared goals
}

\author{
J Sheather
}

\section{See Editorial, p 113}

Correspondence to: Dr J Sheather, Ethics Department, British Medical Association, Tavistock Square, London WC1H 9JP, UK; jsheather@bma.org.uk

Received 8 September 2008 Accepted 17 January 2009

\section{ABSTRACT}

This article looks at a disagreement that emerged at an international human rights conference between health professionals and human rights activists. The disagreement centred on the scope of the responsibilities of health professionals in relation to potential systemic human rights violations. In this article, the nature of the disagreement that emerged at the conference is explored. It is first situated in relation to a strong shared commitment to the "right of everyone to the highest attainable standard of physical and mental health" —often shortened to "the right to health" as it appears in the International Covenant on Economic, Social and Cultural Rights (ICESCR). Some of the tensions that emerged between the participants are then looked at and some of the causes of apparent disagreement identified. The relevance of human rights to health professionals and their impact on medical practice are discussed. Finally, it is argued that, given the common interests shared by these groups, the misunderstandings are not substantive and that there is real scope for mutual learning and collaboration. Although the conference was in southern Asia, the lessons learnt are applicable anywhere in the world - they are equally as relevant to the UK and Europe as to developing countries in the south.

Health professionals and human rights activists can sometimes see the world in very different ways. I was recently invited to talk at a training workshop on health and human rights in southern Asia run by the International Federation of Health and Human Rights Organisations (IFHHRO). The theme of the five-day workshop was "monitoring the right to health". It was hosted by a national medical association with a significant track record in promoting an understanding of the links between human rights and health. There are not many medical associations in the world that have made such a commitment, and it struck me as particularly impressive that it was an association from a middle-income country, where resources can be scarce.

There were 40 or so people at the workshop, divided more or less equally between doctors, other health professionals, medical students and, for want of a more nuanced description, human rights activists: men and women employed directly by civil society groups working in the field of health and human rights. As is often the case with meetings of this kind, I was impressed by the passion and commitment of the delegates. Here were dedicated women and men, often working in difficult conditions, trying to identify concrete ways to improve the well-being of vulnerable human beings. I was therefore both puzzled and upset to see, as the workshop progressed, animosity developing between the medical students and the human rights workers, particularly among the younger members of each group. At one point, I was told that some of the medical students were considering leaving, as they were feeling personally attacked for participating in, or not speaking out about, human rights violations.

In this article, I look at the nature of the disagreement that emerged at the conference. I situate it first of all in relation to a strong shared commitment to the "right of everyone to the highest attainable standard of physical and mental health"- often shortened to "the right to health" as it appears in the International Covenant on Economic, Social and Cultural Rights (ICESCR). ${ }^{1}$ I then look at some of the tensions that emerged between the participants and identify some of the causes of apparent disagreement. I look at the relevance of human rights to health professionals and at their impact on medical practice. Finally I argue that, given the common interests shared by these groups, the misunderstandings are not substantive and that there is real scope for mutual learning and collaboration. Although the conference was in southern Asia, the lessons learnt are applicable anywhere in the world-they are equally as relevant to the UK and Europe as to developing countries in the south.

\section{A RIGHT TO HEALTH}

The topic for the workshop in southern Asia was monitoring the right to health. This right appears as Article 12 of the ICESCR. ${ }^{1}$ (For more information about the content and meaning of the "right to health", see United Nations Economic and Social Council. General Comment 14. The right to the highest attainable standard of health. E/C.12/ 2000/4. http://www.unhchr.ch/tbs/doc.nsf/(symbol)/E.C.12.2000.4.En.) Fairly obviously, the right to health cannot be taken as a right to be healthy; rather it is a progressive right to the enjoyment of a variety of resources and facilities necessary for good health. It is progressive in the sense that it acknowledges that governments are financially restricted in their ability to provide health services. However, it recognises the duty of the state to promote the health of its citizens, and places an obligation upon it to devote more resources to health as they become available. ${ }^{2}$ The aim of the workshop was to look at mechanisms by which the commitment of a state to the right to health could be measured.

Economic, social and cultural rights are often described as "positive" rights, in the sense that they impose a positive obligation on governments 
to secure conditions necessary for their realisation. ${ }^{3}$ These positive rights are often contrasted with "negative" rights, such as the right to free speech, which impose a duty on governments to refrain from interfering with certain basic freedoms (box 1).

Historically, there has been considerable controversy among philosophers and social theorists over the relative status of positive rights and negative rights. ${ }^{4}$ Some have argued, for example, that positive rights should be described as socially valuable goals rather than rights as such. They have also raised questions about whether a "progressive" obligation can meaningfully be understood to impose positive duties.

The philosopher Onora O'Neill has argued that rights to assistance, such as the right to health, cannot be binding until institutional structures exist to articulate and enforce the corresponding duties. ${ }^{5}$ Thomas Pogge recognises this problem, but also argues that we all have "a negative duty not to uphold injustice, not to contribute to or profit from the unjust impoverishment of others". "Still other writers maintain that positive rights follow from the recognition that everyone requires the same basic goods and services to flourish. Hence there can be no good reason to act in ways that deprive anyone of these requirements. ${ }^{7}$ We are rationally and morally compelled to see our own potential hunger and despair in the faces of others who are already suffering and to act appropriately to relieve this.

But, whatever the disagreements about definitional detail, the fact remains that many moral philosophers deplore the existence of extreme poverty and welcome national and international declarations that endorse universal rights to basic need satisfaction. Indeed, one of the reasons why the tensions that emerged at the conference were so difficult to understand was the sheer unanimity of views on this topic. Without access to the basic determinants of health, delegates agreed that people's lives were unacceptably diminished and impoverished.

Illness and disability can impose severe limits on the range of available life options, and can, in certain circumstances, undermine the most passionately held commitments that are central to any notion of a good life. Assistance rights can be seen as tools that can be used to prevent, or to mitigate against, these negative outcomes. Without access to the appropriate provisions and safeguards, even a minimally fulfilling life is unlikely to be possible. This is why many philosophers who disagree about the formal status of the duty to respect human rights

\section{Box 1: negative and positive rights}

In political discourse, "negative rights" are associated with freedom from state interference. The state has an obligation towards the holder of a negative right to refrain from interfering in relation to some fundamental freedom or activity. The right to freedom of thought, conscience and religion is a typical negative right. In a broader, moral understanding of negative rights, the obligation to refrain from interfering with the enjoyment of the rights falls upon all moral actors.

"Positive rights", sometimes known as "rights to assistance", require, in a political context, the state positively to intervene to provide some good or service. The holder of a positive right can make a claim against the state to provide the good or service in question. Typical examples of rights to assistance include the right to social security. Again, in a broader, moral understanding of negative rights, the obligation to refrain from interfering with the enjoyment of the rights falls upon all moral actors. claims still agree about the importance of the goals stipulated by such claims. So why was there such animosity between health professionals and human rights activists, given such a fundamental consensus?

\section{RIGHTS AND RESPONSIBILITIES: UNDERSTANDING THE NATURE OF THE DISAGREEMENT}

It is important to understand what was at issue. The disagreement was not about that tiny minority of doctors who have actively and knowingly violated ethical norms represented in negative rights of liberty, autonomy and integrity. This was not about Nazi doctors or doctors complicit in brutal interrogation, nor was this about rogue doctors, about a Harold Shipman or a Rodney Ledward. (Harold Shipman and Rodney Ledward were both doctors from the UK. Harold Shipman was a general practitioner who was found guilty of the murder of over 200 of his patients. Rodney Ledward was a consultant gynaecologist who was found guilty of serious medical misconduct by the UK General Medical Council for "bungling" operations on 13 patients.) Nor was the disagreement linked to private medicine, to concerns about doctors working in the private sector neglecting to treat the impoverished sick. This was about hard-working doctors in state-funded health systems who were operating within established social care systems and according to established medical practice. So again, why the antagonism?

In part, doctors were being criticised because they were the most visible and senior members of the health professions and were therefore held to have a major responsibility for the failings of the system. State-funded health services throughout the world are imperfect, overpressured and under-resourced. In spite of the best intentions, they sometimes damage and dehumanise the people that move through them. For many patients, it can seem that medicine is more interested in sickness than in people, more interested in biological faults than in the people that experience them. In this way health systems can seem to compound the indignities and vulnerabilities of ill health. Iatrogenic illness, the toll of psychological attrition that large institutions can levy, the reality of rationing, all of these can too easily be laid at the door of professionals who work within the system and who can often seem blind to its failings.

To put this in a more legal framework, under international human rights law, the bulk of duties to promote human rights fall upon governments-known as "states parties" in legal jargon. ${ }^{8}$ As Nickel puts it, "human rights are political norms dealing mainly with how people should be treated by their governments and institutions". " The allocation of public resources is clearly the proper business of the state. As a result, human rights groups tend to focus attention on the activities of governments-both the things they do and the things they decline to do.

This attention properly extends to individuals working for governments, such as health professionals directly employed by public health services. Negative aspects of government responsibilities extend to ensuring that both public and private actors do not undermine the right to health. For example, powerful commercial interests, such as mining companies and petrochemical corporations, must be prevented from degrading the environment and damaging the health of the population. For an interesting account of the relationship between human rights norms and powerful national and commercial interests, see Macdonald ${ }^{9}$ (particularly chapters 2 and 7).

Human rights groups working on the right to health will therefore tend to turn their attention to the activities of 
governments, their agents and important commercial actors. They will look at, and often criticise, the shortcomings of both public health services and those regulatory agencies responsible for protecting citizens from harm. Their approach will often be legalistic, articulated in a language of obligations and violations. As such, it can sometimes seem a stark, black-and-white world of clear rights and wrongs in which health professionals, particularly doctors, are blamed for problems beyond their control.

This was one of the key sources of antagonism at the workshop in Asia. Human rights activists saw health as an arena of collective duties and responsibilities, whereas health professionals took a much more pragmatic approach: how do we help this person in this situation, how can we adapt our practice to make ordinary standards fit extraordinary situations?

\section{INDIVIDUAL AND COLLECTIVE RESPONSIBILITIES: UNDERSTANDING WHERE DUTIES LIE}

The root of the problem was linked to a basic misunderstanding about the scope of doctors' responsibilities. Doctors were seen as synonymous with the systems in which they worked, and within which they often found themselves struggling. The health professionals felt under attack because they were being personally identified with the failings of their institutions. The human rights workers were expressing frustrations about system-wide abuses and did not understand why the doctors did not appear to be more committed to change.

If this was the problem, then it seemed to me that at least part of the solution would be an unpacking and elaboration of the duties and responsibilities that devolve from high level rights. Put more simply, a more nuanced understanding was required about who is responsible for what, and to what extent. ${ }^{10}$ Without a more balanced and subtle sense of the scope of obligations, the risk would always remain that debate about human rights could decay into crude sloganeering, alienating precisely those people central to the upholding of the right itself.

Yet the question of whom to hold responsible for violations of human rights is itself fraught with difficulty. In the absence of political and judicial institutions that clearly delegate such responsibility, one is left with the obviously immoral behaviour of individuals in power (eg, Robert Mugabe) or oppressive states (eg, Sudan) or the more morally opaque activities of commercial companies or international institutions. However, two things are clear with regard to this issue of accountability.

Firstly, responsibility should be focused on those who can most easily relieve the hardship that human rights violations impose. This will usually mean that responsibility should be both individually and institutionally attributed. Individuals are often only able to violate such rights with institutional backing. For example, the fact that international treaties and tariffs allow corporations to buy land and minerals from dictatorships reinforces the ability of dictators to spend this money on arms to keep themselves in power and to oppress the people whom they should serve. ${ }^{11}$

Secondly, despite the visibility of such violations of rights, there are few means by which either individuals or institutions can be brought to justice. Nationally, corruption often extends to the judiciary. Internationally, the scope of potential venues for trial and punishment is limited (for an account of available international human rights monitoring mechanisms, see Steiner and Alston ${ }^{12}$ ). Hence frustration and the search for someone to take responsibility for ostensible human rights violations are easy to understand.

\section{Main messages}

- The right to the highest attainable standard of physical and mental health is a key human right recognised in international law. It aims to create conditions necessary for human flourishing.

- Health professionals and human rights activists can share genuine disagreements as to the nature of individual obligations in relation to this right.

- Human rights activists will often focus on the obligations of states and their actors.

- Health professionals will often focus on their obligations to individual patients.

- Health professionals and human rights activists share common commitments, and their underlying goals are profoundly sympathetic.

\section{THE VIEW FROM BRITAIN}

Experience from the UK can help to clarify this issue of responsibility. Here, the entitlement to healthcare based on need and free at the point of delivery is recognised in law. Although there may be problems about its resourcing and delivery, this is a recognised-though limited-human right, which all citizens can expect to be respected. As a result, patients continue to embrace the moral values of the NHS itself. It remains the most popular state institution, not least because patients believe that their rights are respected by most of those who care for them.

Within the UK, medicine is financed by the state through taxation. It is a single-payer system in which individual fees for service play no part. Hence major potential constraints on respect for human rights are removed. But the NHS itself is not without problems. The constant "re-engineering" of the last two decades has both highlighted and often exacerbated its organisational and financial limitations, which may put respect for human rights at risk, however committed the health workers. ${ }^{13}$

Morally committed health professionals are aware of the system's shortcomings, and will work hard to maximise patient care, sometimes in the face of considerable difficulty. Indeed they may even see their relationship to the health system as oppositional, believing that they do their work in spite of its failings. They have a clear responsibility to act when they think that systemic failings may be putting patients at risk. If it is within the individual's power to solve the problem, then he or she should do so; otherwise they should report the matter to proper authorities. ${ }^{14}$

Thus the proper practice of healthcare in the context of an institution such as the NHS exemplifies respect for human rights. As Doyal et al ${ }^{15}$ point out in the editorial of this issue, when doctors are doing their best, they are not just medical practitioners; they are also human rights activists. It is this reality that leads doctors to feel aggrieved when they are criticised by others for not being "onside". This will be especially frustrating when these same critics do not recognise the skills and the moral courage that are vital for excellence in clinical care. Equally, doctors may fail to respect the extent to which these same critics work hard to bring improvements to the institutional, economic and political environment in which they practise medicine. 


\section{CONCLUSIONS}

My experience in Asia highlighted the extent to which both the moral practice of medicine and advocacy in pursuit of human rights are based on common commitments. Both acknowledge the special moral significance of healthcare as one of the foundations upon which the realisation of human potential can be built. However, health professionals tend to focus on meeting individual health needs and alleviating individual suffering. Human rights activists, on the other hand, usually see health as a social and legal contract. They are sensitive to the obligations of states and to the activities of the relevant agents and agencies.

There is obviously scope for critical disagreement between the two groups, but the underlying goals are profoundly in sympathy. What is required is a more sophisticated understanding of the nature of human rights obligations in healthon their nature, their scope and the individuals and groups upon whom they fall. We can then acknowledge and welcome the shared understanding that both the practice of medicine and the protection of human rights are at the heart of our moral commitments one to another.

Competing interests: None.

\section{REFERENCES}

1. International Covenant on Economic, Social and Cultural Rights. Article 12(1). See Steiner HJ, Alston P. International human rights in context. Oxford: OUP, 1996:1178.

2. British Medical Association. The medical profession and human rights. London: BMA, 2001:chapter 13.

3. Nickel J. Human rights. Stanford encyclopaedia of philosophy. http://plato.stanford. edu/entries/rights-human/ (accessed 20 Feb 2009).

4. Beetham D. What future for economic and social rights? Polit Stud 1995:41-60.

5. O'Neill 0. Towards justice and virtue: a constructive account of practical reasoning. Cambridge: CUP, 1996.

6. Pogge T. World poverty and human rights: cosmopolitan responsibilities and reforms. Cambridge: Polity Press, 2002:197.

7. Gewirth A. Duties to fulfill the human rights of the poor. In: Pogge T, ed. Freedom from poverty as a human right. Oxford: OUP, 2007:219-36.

8. Toebes, BCA. The right to health as a human right in international law. Oxford: Intersentia-Hart, 1998.

9. Macdonald TH. Health, human rights and the united nations. Oxford: Radcliffe, 2008.

10. Ashford E. The duties imposed by the human right to the basic necessities. In: Pogge T, ed. Freedom from poverty as a human right: who owes what to the very poor? Oxford: OUP, 2007:189-90.

11. Pogge T. ed. Freedom from poverty as a human right: who owes what to the very poor? Oxford: OUP, 2007:42-3.

12. Steiner HJ, Alston P. International human rights in context. Oxford: OUP, 2000.

13. British Medical Association. A rational way forward for the NHS in England. London: BMA, 2007.

14. General Medical Council. Good medical practice. London: GMC, 2006:6.

15. Doyal L, Doyal L, Sokol D. Good medicine, human rights and the rights of doctors. Postgrad Med J 2009;85:113-14. 